International Journal of Social Science (IJSS)

Vol.1 Issue.5 February 2022, pp: 563-568

ISSN: 2798-3463 (Printed) | 2798-4079 (Online)

\title{
THE IMPLEMENTATION OF AREA GOVERNMENT POLICY IN WASTE PROCESSING, JAYAWIJAYA REGENCY, PAPUA PROVINCE, INDONESIA
}

\author{
By \\ Nur Aini', Taufik Rachman², Yotam Giban ${ }^{3}$ \\ 1,2,3Fakultas Ilmu Sosial Dan Ilmu Politik, Universitas Amal Ilmiah Yapis Wamena, Jayawijaya, 99551, Papua, Indonesia \\ Email: $\underline{\text { ainimuhtadi@gmail.com }}{ }^{1}, \underline{\text { tarawmx70@gmail.com }}^{2}$, gibany976@gmail.com $^{3}$
}

\begin{tabular}{l}
\hline Article Info \\
\hline Articlehistory: \\
Received Nov 8, 2021 \\
Revised Dec 26, 2021 \\
Accepted Jan 15, 2022
\end{tabular}

Keywords:

Implementation, Policy, Management, Waste

\begin{abstract}
The implementation of local government policy in waste management, at Jayawijaya Regency, Papua Province, is a very strategic step that aims to serve the waste generated by the population, which indirectly participates in maintaining public health and creating a clean environment. To know performance rather than policy implementation, the authors perform analysis of the implementation of waste management policies, identify and analyze the supporting factors and inhibiting factors in waste management, and efforts to improve the effectiveness of implementing waste management policies at Jayawijaya Regency. This research is qualitative research with a descriptive approach. The results of the research indicate that factors are influencing the implementation of waste management policy, namely; that thereare unclear contents of the policy that is not understood by the community related to communication due to the level of knowledge, the authority is the supervision of the field thathandles the cleanliness of the city related to the resources and also the means of infrastructure, dispositions related to cognition and organizational structure related to the coordination found in the organizational structure. Still using a manual system, which is done by dumping (stacking). Waste management in the final disposal site is still conventional or combustion system. Efforts to improve the effectiveness of local government policy implementation in waste management are by applying local regulations that have been made seriously in the handling of waste. Awareness of the responsibility of the cleanliness officers should be improved. The need for supervision of the field of handling and processing of waste directly inthe field from the environmental agency.
\end{abstract}

Thisisan open accessarticleundertheCC BY-SAlicense.

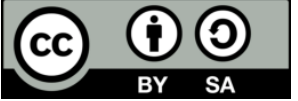

\author{
CorrespondingAuthor: \\ Nur Aini, \\ Fakultas Ilmu Sosial Dan Ilmu Politik, \\ Universitas Amal Ilmiah Yapis Wamena, Jayawijaya,99551, \\ Papua, Indonesia \\ Email: ainimuhtadi@gmail.com
}

\section{INTRODUCTION}

The increase of population and changes in the consumption pattern of the community lead to increased volume, types, and characteristics of increasingly diverse waste. Waste has become a National problem so that its management needs to be done comprehensively and integrated; waste management required legal certainty, clarity of government responsibility and authority, area government, as well as the role of society sothat waste management can run professionally, effective and efficient. Then the President issued Law RI No. 18, in 2008, on waste management aimed at reducing waste problems in Indonesia.

Every activity carried out by humans always produces waste and almost every dayhumans generate waste. If the waste is not properly managed, it will cause various problems such as aesthetic problems because of the smell it causes, become a disease factor, and can disrupt the soil and groundwater quality. 
To prevent disturbances to the environment and human health, it is necessary to design a good waste management system from waste storage, garbage collection, transport and transportation, garbage processing, and garbage disposal to the final disposal. The design of a waste management system of a region required data on the waste dump, composition, and characteristics of waste generated in the planned area.

Thomas R Dye (2011: 1), defines public policy as " is whatever government chooses to do or not to do" (whatever the government chooses to do or not to do). This definition emphasizes that public policy is regarding the manifestation of "action" and nota statement of the wishes of the government or public officials alone. Besides the government's choice to not do something is also a public policy because it has influence (the same impact as the government's choice to do something).

James E. Anderson defines the policy as the behavior of several actors (behavior, groups, and government agencies) or a series of actors in a particular field of activity. Policy talks can not be separated from the inter-group interests, both at the level of government and society in general, (Anderson, 1979: 2-3).

The public policy contains at least three basic components, that is: (1) goals achieved, (2) specific goals, and (2) how to achieve targets. How to achieve this goal is often called the implementation, which is usually translated into action programs and projects. This implementation activity is usually contained therein: who the executor, largefunds and sources, who is the target group, how the program or project management, and how the success or performance of the program is measured. It can be said that policy implementation is a way for a policy to achieve its goals. Nothing more and nothing less. The purpose of the policy is essential to intervene. Therefore the actual implementation ofthe policy is the action of the intervention itself.

The policy implementation is the application of public policy. Policy implementation is the strategy where a public policy has been formulated. Managed to be formulated or implemented. The implementation of public policy is an effort to achieve the goal of public policy, Riant Nugroho (2014:110).

George Edward III ( 1980: 1 ) noted that the main issue of public policy is the lack of attention to the implementation of public policy. Expressly stated that without effectiveimplementation, policy makers' decisions will not be successful. Edward suggested paying attention to four major issues: communication, resources, disposition, attitude, and bureaucratic structure.

Communication is in terms of how the policy is communicated to the public to obtain responses from the parties involved. Resources are related to their availability, especially human resource competencies and the capability to implement policies effectively. Disposition is in terms of the willingness of actors to implement policy. Disposition is about commitment, more than competence and capability. The bureaucratic structure is in terms of the challenge of not becoming a fragmentation of the bureaucracy, as it decreases the effectiveness of policy implementation.

The management of a town's garbage aims to serve the waste generated by its inhabitants, which indirectly participates in maintaining public health and creating a cleanenvironment. The current management of garbage faces a lot of pressure mainly due to theincreasing amount of waste generated, then can be imagined with a community of about 484,751 people (source: BPS Jayawijaya Regency, 2021), disposing of waste dumped in Pisugi area where the final disposal, lack of attention from the government in this case environment agency Jayawijaya Regency, which waste management has not been handledproperly.

According to Manik (2007:67) waste is defined as "an object that is not used or notdesired and must be desired and must be discarded, which results by human activities". Thus, waste can come from industrial activities, mining, animal husbandry, fisheries, transportation, household, trade, and other human activities. The management of a region'sgarbage is determined by the rules that support it. These regulations involve the authority and responsibility of hygiene management and public participation in maintaining cleanliness and levy payments. Various area regulations which are the legal basis for wastemanagement are:

a. Area regulations associated with the general provisions of hygiene management intended for the community.

b. Regional regulations on the establishment of formal institutions.

c. Regional regulations that determine the tariff structure and basic tariffs of cleanlinessmanagement.

Operational techniques of waste management start from storage/storage on waste sources, collection activities, transporting, processing, and disposal in a safe place and notdisturbing the environment of humans, flora, and fauna, or other resources.

Soekmana (2010) says that "Management of waste generated from human activities, grouped into six separate elements, namely first, control of generation". Second, storage. Third, collection. Fourth, transport and transportation. Fifth, processing, and sixth,that is disposal. 
International Journal of Social Science (IJSS)

Vol.1 Issue.5 February 2022, pp: 563-568

ISSN: 2798-3463 (Printed) | 2798-4079 (Online)

DOI: https://doi.org/10.53625/ijss.v1i5.1295

Further according to Soekmana (2010) states that "waste management with the six elements must be implemented with principles that can guarantee public health and implemented according to economic, technical, conservation, aesthetic and other considerations".

The above view shows that good waste management will produce a well-ordered and neat environment, as well as provide added value for the community of area government entrepreneurs as regional institutions that have authority in waste management, and also gave birth to a clean and healthy environment for every community, especially waste management at Jayawijaya Regency.

Until now, garbage is still a serious problem in various countries including in Indonesia, as the problem of waste management at Jayawijaya Regency, Papua Province. The handling system still relies on the Final Disposal Site, like a garbage dump. Not optimal use of organic and nonorganic waste into something that has a positive value bothin economic and environmental. Community participation in the cleanliness of the environment is still not seen despite the existence of area regulations, which regulate the implementation of road order and public facilities, cleanliness, and beauty. Because the problem is also the author poured his mind to raise the waste problem through this researchabout the reality that exists at Jayawijaya Regency.

The implementation of environmental cleanliness for public health Jayawijaya Regency is very important. The waste handling process is not proportional to the daily garbage volume. For that, it needs serious handling from the government to address it.

Through the regulation of the government is expected to awareness for every citizen of thecleanliness of the neighborhood environment, shops, offices, and places of education. Because waste affairs are not only government affairs but also require broad community participation.

Research on the implementation of waste management policies, among others: Dynamic Model of Waste Management to Reduce Stacking Expenses (Journal of industrial engineering, Vol. 11, 2009, pp.134-147). In this research, the analysis of waste management to reduce the burden of waste in the Final Disposal Site, using a simulation- based on the dynamic system approach. The next simulation results will be used to see thefeasibility of each alternative waste management based on the calculation of Cost-Benefitratio (B / C), while to know the society view of waste treatment alternative (seen from the social aspect, economics, environment, and technology), hence also conducted the process of weighting with Analytic Hierarchy Process (AHP). As a case study selected Bantar Gebang landfill that serves to accommodate waste generated by DKI Jakarta. By using the simulation, the projected garbage produced and will be disposed to Bantar Gebang Landfillfor various scenarios until 2025. Based on the results of analysis, both with dynamic system and with Analytic Hierarchy Process (AHP) and Benefit-Cost ratio (B / C), it is better to manage waste in DKI gradually, first is by composting and then with the incinerator.

The Household Waste Management In South Daha District (Journal of Environmental Science Vol.9, 2011). This observational analytic study aims to examine household waste management and correlated factors and to plan community-based waste management. Household waste management in Kecamatan Daha Selatan has not been implemented optimally. The level of education, income level, behavior toward environmental hygiene, knowledge of Gerda, and willingness to pay garbage levy has a positive correlation with household waste management.

The Analysis of Urban Waste Management (case study at Boya Sub-District Banawa District Donggala District) (Journal of SMARTek, Vol 9, 2011: 155 - 172). The purpose of this study is to know the implementation of waste management in Donggala City as well as to know the factors that influence waste management in Donggala City. The results of the study found that the management of garbage in Donggala City is good enough. The several factors affecting waste management in Donggala City are community participation, staff education level, and the number of cleaning personnel.

The Government Policy in Domestic Waste Management (Journal of Public Health, Vol 8, 2014). The purpose of this research is to know the government policy in managing domestic waste in Yogyakarta Special Region (DIY), change of environment and society quality due to waste management policy, and to know the method of monitoring and wastemanagement in DIY. Trash transported to landfills is still low compared to the volume of waste generated. Policies for waste management are in all districts/cities of DIY has established bodies/units responsible for managing waste. Changes in the quality of the environment and society are the environment and the road to be clean, beautiful, and comfortable. The method of monitoring and evaluation of waste management policy in DIY has not been poured into the standard procedure. The problem of waste has become aconcern for the local government of DIY. The policies have been supported by specific service, project, regulatory, and incentive programs for waste management.

Based on the above description the authors are interested in researching the implementation of local government policies in waste management. This study is used as a regulation of the Regional Regulation, No. 10/2011, article 8, chapter III, on the implementation of road order and public facilities, cleanliness, and beauty. In 
this study, the researcher uses the theory of policy implementation of George Charles Edward III which, according to the author by the reality that occurred in the place of research.

\section{METHODS}

The type of research in the implementation of area government policy in waste management at Jayawijaya Regency is qualitative research with a descriptive approach. The focus of observation in this study by looking at the implementation of area governmentpolicy in waste management for the implementation of environmental hygiene for public health seen in the form of cleanliness program on waste storage aspect, garbage collection, waste removal, and garbage collection, garbage processing, and waste collection (Soekmana, 2010).

Then also seen from the implementation of policy on supporting factors and constraining factors according to George C. Edward III, namely: communication, resources, disposition/ attitude, and organizational structure.

The data in this study were collected from primary data sources and secondary datasources. The selection of this informant has been based on the consideration that the informants are the formulators or policy-making actors, policymakers and implementers as well as officials and officials of the Environmental Agency's cleanliness. The data collection was done by participant observation method, in-depth interview, documentary method, and triangulation. As a key instrument in this study, researchers go directly to conduct data collection through observation and in-depth interviews in the field.

The data obtained through data collection techniques are the method of in-depth interviews, participant observation, and documentary method in the analysis by using qualitative analysis. Through this analysis, the results of the study are described or described to obtain a complete of the study subjects. The analysis activity consists of theirsimultaneous activity flow that is data reduction, data presentation, and the conclusion/verification. In this study, researchers used data credibility techniques and dataconfirmability to test the validity of data.

\section{RESULTS AND DISCUSSION}

The waste management at Jayawijaya Regency has not been running well, especially in the final disposal area, in the village of Pisugi, Pisugi District. The village of Pisugi has an area of $21.897 \mathrm{~m}^{2}$. The final disposal of Pisugi is by Ministerial Regulation No. 21/2006, about policy and strategy of the waste management system at Indonesia National Standart (03-3241-1994), on the procedure of choosing the location of the landfill, and then the Jayawijaya regency government uses the sanitary landfill method.

There are indicators of research variables, namely in the form of waste storage, garbage collection, transport and transportation of garbage, garbage processing, and garbage disposal. There are also supporting factors and factors inhibiting the implementation of area government policies in waste management, namely: communication, resources, disposition/attitude, and organizational structure.

The through observation is known that the effort ineffectiveness of the implementation of waste management policy is still low, not all people understand the purpose and purpose of the program. Thus, serious regional regulation is required in the handling of the garbage. The awareness of janitors must be improved. The supervision should be carried out from the field of Penanggulangan and Pengelolaan Limbah directly in the field. The interviews conducted by several informants stated that "the implementation of waste management policy has been implemented by the Field of Waste Management and Management, since the issuance of Local Regulation no. 10 the Year 2011 until now, but the programs that have not run effectively. Must be careful planning in making program activities until program implementation and program achievement ".

The supporting factors that influence the implementation of area government policy in waste management, among others; the existence of area regulations governing the implementation of road order and public facilities, cleanliness and beauty, the motivation of operational officers that can be developed, the inclusion and disposal of waste, and in the implementation of the program, the implementation of the program has been based on SOP.

The inhibiting factors that affect, among others; there are still people who do not follow the time rules to dispose of the waste, which has been determined in the area regulations. There are still people who dump garbage, not in the Provisional Disposal Place, that has been provided but create a new mound of garbage on the road side. This could be the cause of environmental pollution. The level of knowledge and the attitude of the community about waste management is still low so that it affects environmentally conscious behavior. In lowland areas, if the rainy season is often affected by flooding. Piles of garbage carried by the swift flow of water can be a cause of health problems. The lack of supporting facilities and infrastructure for janitors. Pisugi Disposal Place still uses a manual system, which is done by dumping. The waste Management in the Final Disposal Site is still conventional or combustion system.

The environmental awareness-raising activities to the community should be undertaken to encourage community participation in waste management, the approaching is a community of leaders about waste management 
International Journal of Social Science (IJSS)

Vol.1 Issue.5 February 2022, pp: 563-568

ISSN: 2798-3463 (Printed) | 2798-4079 (Online)

DOI: https://doi.org/10.53625/ijss.v1i5.1295

programs, the approaching of the community leaders, cooperate with government agency and business entities, the should be added equipment hygiene supporting facilities and conduct maintenance or maintenance of garbage transport vehicles, it would be possible to recycle waste business with economicvalue.

\section{CONCLUSION}

The based on the results of the discussion, then the conclusion of research implementation of area government policy in waste management has not run effectively. The waste management process has not run well because it is still dumping (stacking) which destruction is still with the conventional system or burned.

The results of the research indicate that factors are influencing the policy of wastemanagement, namely: a. Communication, on these communication factors that support the transmission: waste management policy has been implemented. The obstacles are the content of policies that should always be disseminated to the public, the level of knowledge, and the attitude of the community about waste management is still low so thataffect the environmentally conscious behavior, b. Resources, as support policy implementation that is the process of waste management undertaken by the janitor as a target and as an obstacle to the authority to execute the policy effectively, lack of facilitiesand infrastructure, c. Disposition, which is the support of the direction and response from the implementer, then the obstacle is the cognition that is less understood by the implementer of the implementation of management policy, d. Organizational structure, its supporters have Standard Operating Procedure (SOP), which is the obstacle that is of organizational structure related to coordination.

The great attention from the area government in terms of waste management should be improved through socialization to the community, the raising awareness of the cleaners as well as the community of Wamena city in terms of improving environmental hygiene in preventing health problems. Apply the Regional Regulations that have been made seriously in the handling of the ships. Awareness of the responsibilities of the cleanliness officers should be improved. It is necessary to supervise the field of prevention and processing of waste directly in the field from the Environment Agency.

\section{REFERENCE}

[1] Anderson, James E, 1979-second edition, Public Policy Making, Holt, Rinehart andWinston, New York

[2] Dye, Thomas R, 2011, Understanding Public Policy, Second Edition, Englewood Cliff, New Jersey: prentice-Hall

[3] Edward III, George C, 1980, Implementing Public Policy, Washington: CongressionalQuarterly, Inc

[4] Indiahono, Dwiyanto, 2009, Public Policy Based on Dynamic Policy Analysis, Yogyakarta: Gava Media. Cetak First

[5] Manik, Sonntag, Karten, Eddy, 2007, Environmental Management, Djambatan, Jakarta

[6] Riant, Nugroho, 2014, Policy Research Methods, Pustaka Belajar, Yogyakarta, Second Printing

[7] -----------, 2015, Public Policy in Developing Countries, Pustaka Belajar, Yogyakarta, Second Printing

[8] Soekmana, Soma, 2010, Introduction to Environmental Engineering, Bogor, IPBPress

[9] I, Akhmad, \& Ade, Dynamic Model of Waste Management to Reduce Stacking Expenses, Journal of Industrial Engineering, Vol. 11, No. 2, December 2009, pp. 134-147, ISSN 1411-2485

[10] Riswan, Henna, Agus, Household Waste Management In South Daha District, Journalof Environmental Science, Vol. 9, No. 1, April 2011

[11]Rizal, Mohammad, Analysis of Urban Waste Management (Sudi case in Kelurahan Boya, Banawa District, Donggala District), Journal of SMARTek,

[12] Mulasari, Husodo \& Muhadjir, Government Policy on Domestic Waste Management, Public Health, Journal of National Public Health, Vol. 8, No. 8, Mei 2014

[13] The Law No.18/2008 on the Management of Samples

[14] Regulation of Minister of Public Works No.21/PRT/2006 on Policy and National Strategy of Development of Waste Management System (KSNP-PP)

[15]Regulation of Jayawijaya Regency No.10/2011 Regarding The Implementation of Road order and Public Facilities, Cleanliness, and Beauty

[16] Dissemination and Socialization of Engineering PLP/ material I field of waste

[17]BPS, Jayawijaya Regency, 2021 
